$$
\begin{aligned}
& \text { جداسازى و شناسايى مولكولى باكترىهاى توليد كنندهُ كاروتنوئيد }
\end{aligned}
$$

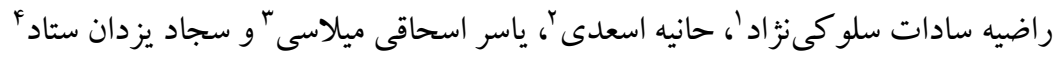

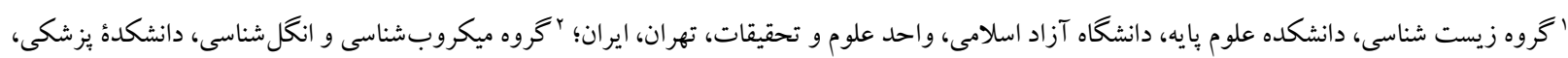

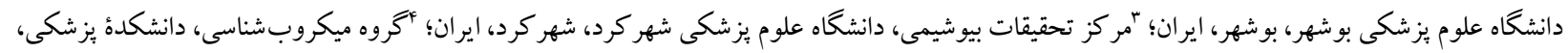

$$
\begin{aligned}
& \text { دانشكاه علوم يزشكى كلستان، كر كان، ايران }
\end{aligned}
$$

نويسنده مسئول: سجاد يزدان ستاد، S.yazdansetad@goums.ac.ir

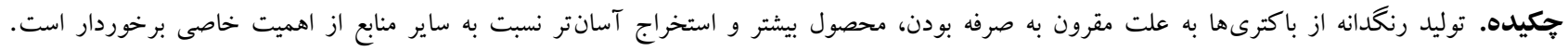

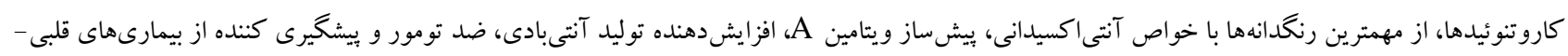

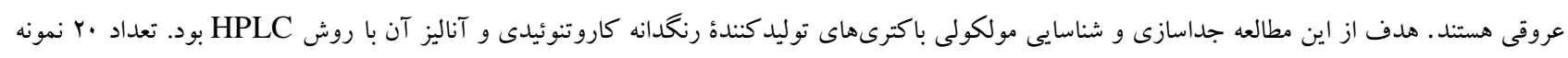

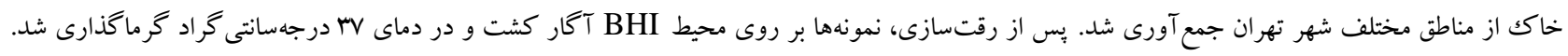

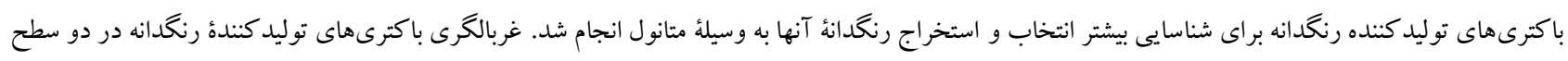

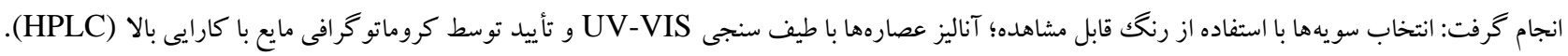

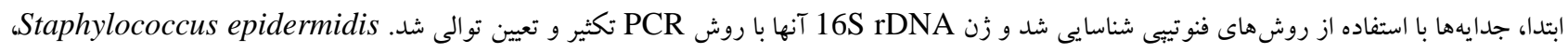
Dietzia natronolimnaea،Arthrobacter agilis ‘Rhodococcus zopfii ،Citricoccus alkalitolerans ،Micrococcus aloeverae و بهنوان سويههاى توليدكندة كاروتنوئيد شناسايى شدند. بالاترين ميزان جذب با استفاده از آناليز طيفسنجى Uhodococcus ruber HPLC Hietzia natronolimnaea و Staphylococcus epidermidis

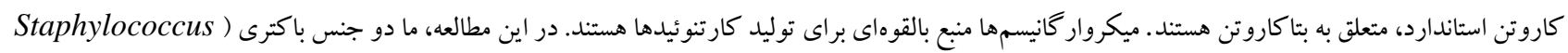
(Dietzia natronolimnaea و با توانيى بالاى توليد كار تنوئيد معرفى كرديم.

$$
\text { وازههاى كليدى. بتاكاروتن، رنخدانه، كاروتنوئد، كروماتو كرافى، طيف سنجى }
$$

\title{
Isolation and molecular identification of carotenoid-producing bacteria
}

\section{Razieh Sadat Solouki Nezhad ${ }^{1}$, Hanieh Asaadi ${ }^{2}$, Yaser Eshaghi Milasi ${ }^{3}$, Sajjad Yazdansetad ${ }^{4}$}

${ }^{1}$ Department of Biology, Faculty of Basic Sciences, Islamic Azad University, Science and Research Branch, Tehran, Iran; ${ }^{2}$ Department of Microbiology and Parasitology, Faculty of Medicine, Bushehr University of Medical Sciences, Bushehr, Iran; ${ }^{3}$ Clinical Biochemistry Research Center, Shahrekord University of Medical Sciences, Shahrekord, Iran; ${ }^{4}$ Department of Microbiology, School of Medicine, Golestan University of Medical Sciences, Gorgan, Iran Correspondent author: Sajjad Yazdansetad, s.yazdansetad@goums.ac.ir

\begin{abstract}
The production of pigments from bacteria is significant due to the low cost, high yield and ease of extract compared with other sources. Carotenoids are one of the most important pigments with antioxidant properties which are the precursor of vitamin A synthesis and have antibody overproduction ability, anti-tumor activity and inhibitory effect on the cardiovascular disease. The present study aimed to isolate and identify carotenoid-producing bacteria by highperformance liquid chromatography (HPLC) analysis of their carotenoid pigments. Twenty soil samples were collected from different regions of Tehran. After serial dilution each sample was cultured on BHI agar medium and incubated at $37^{\circ} \mathrm{C}$. The pigment-producing bacteria were selected for further identification and their pigments were extracted by
\end{abstract}


methanol. The screening was carried out at two levels: i) selection of the strains by visual color inspection, ii) analysis of the pigment extracts by UV-VIS spectroscopy and HPLC. The isolates were identified by phenotypic methods and their 16S rDNA gene was amplified by PCR method and sequenced. Staphylococcus epidermidis, Micrococcus aloeverae, Citricoccus alkalitolerans, Rhodococcus zopfii, Arthrobacter agilis, Dietzia natronolimnaea and Rhodococcus ruber were identified as carotenoid-producing strains. The highest rate of absorption was observed using UV-VIS analysis in Staphylococcus epidermidis and Dietzia natronolimnaea. The comparison of HPLC analysis with the standard $\beta$-carotene curve showed that the carotenoids were beta-carotene. Micro-organisms are a potential source in the production of pigments. In this study we introduced two genera of bacteria (Staphylococcus epidermidis and Dietzia natronolimnaea) with carotenoid-producing ability.

Keywords. $\beta$-carotene, carotenoids, chromatography, pigment, spectrophotometry

Sinha et al., 2017; ) كمتر و سهولت در كنترل توليد است dolo Naziri et al., 2014 انتشار گسترده، تنوع ساختارى و نقشهاى متعدد يكى از مهمترين كروههاى رنخدانهاى هستند (Asker et al., 2007). كاروتنوئيدها

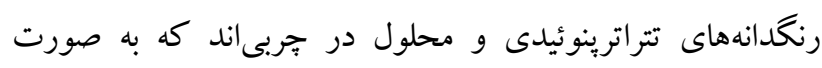
طبيعى در كلرويلاست و كرومويلاستهاى گياهان و بعضى از

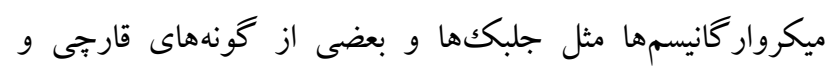
باكتريايى يافت مىشوند (Paniagua-Michel et al., 2012).

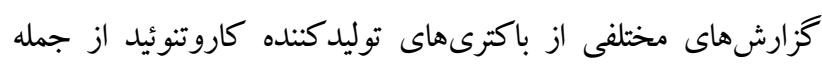
Halorubrum ،Balraj et al., 2014) Exiguobacterium sp. Serratia marcescens ‘(Naziri et al., 2014) sp.

Chromobacterium violaceum gtreptomyces coelicolor وجود دارد. اين مطالعه، با هدف جداسازى (Ahmad et al., 2012) و شناسايى باكترىهاى توليد كنندة كاروتنوئيد از خاكك و آناليز

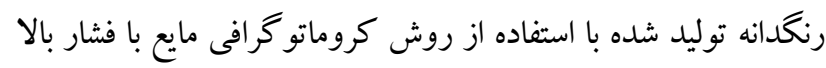
(HPLC)

\section{مواد و روشها جمع آورى نمونه}

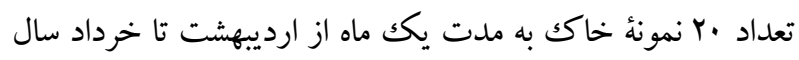

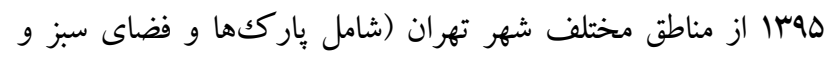

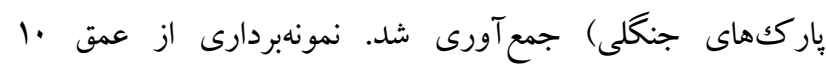

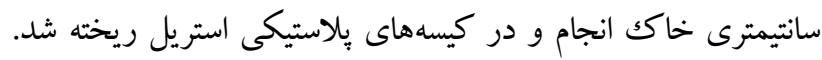

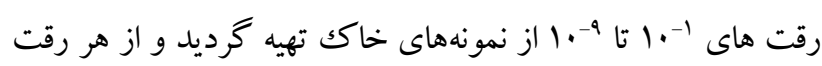
در محيط آكار عصارءٔ مغز و قلب (Brain Heart Infusion Agar)

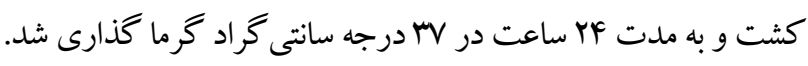
جداسازى و شناسايى باكترىهاى توليد كننده رنعدانه بسيارى از رنغكهاى سنتيكك كه امروزه در صنايع مختلف غذايى، دارويى و غيره به كار مىروند داراى اثرات مضر متعددى هستند.

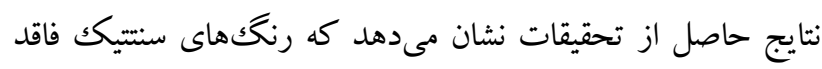

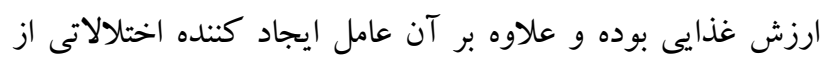

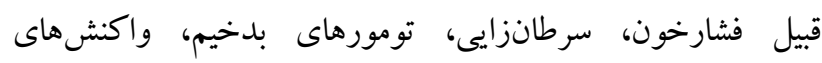

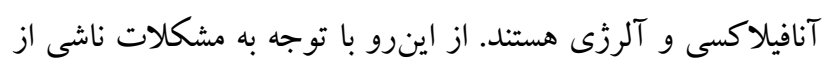

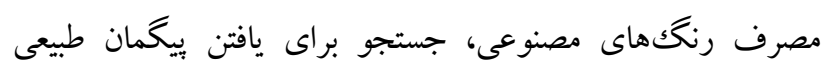

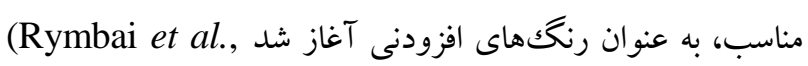
(2011; Seifzadeh et al., 2016) كلى از ميوهها، سبزيجات، دانهها، ريشهها و ميكروار كانيسمها

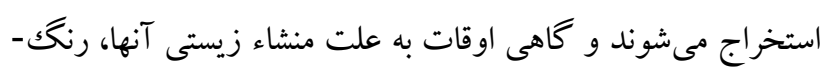
هاى زيستى ناميده مىشوند (Parmar \& Phutela, 2015). اين

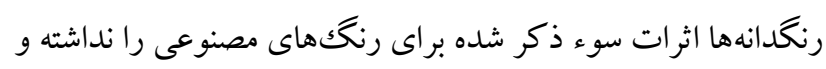

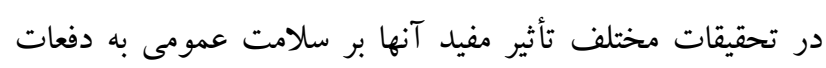

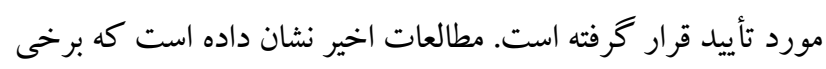

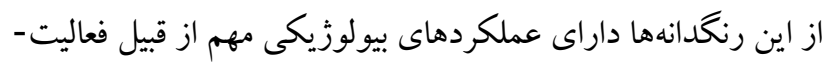

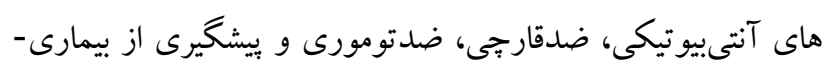

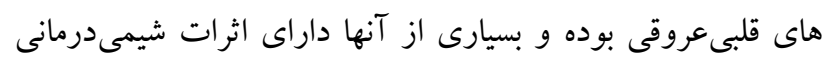

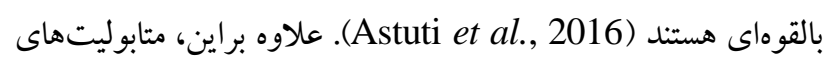

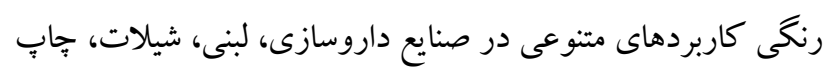

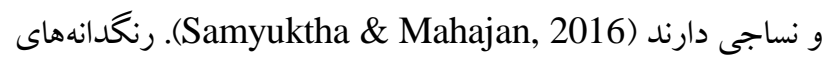

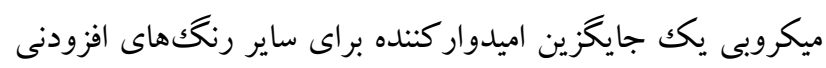

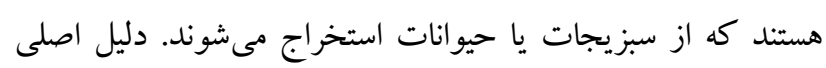

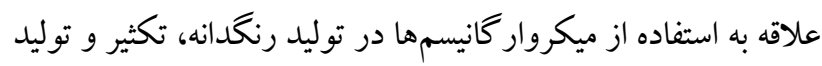
بالا با استفاده از دستكارىهاى زيستى و زُنتيكى است. بعلاوه، توليد

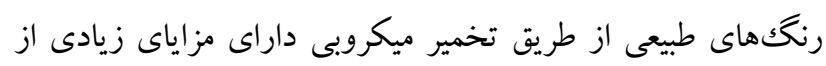

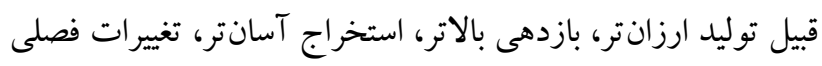


باكترىهاى توليد كنده رنگدانه در محيط كشت نوترينت براث

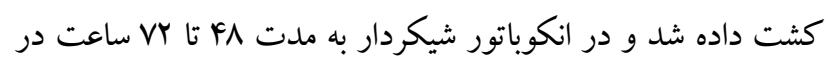

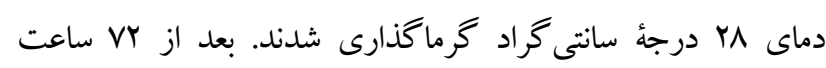

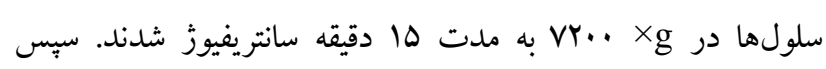

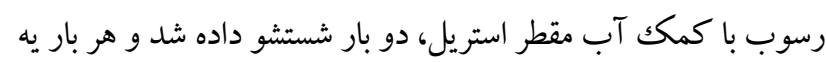
مدت ها دقيقه سانتريفيوز گرديد. در نهايت رنغدانه با استفاده از متانول

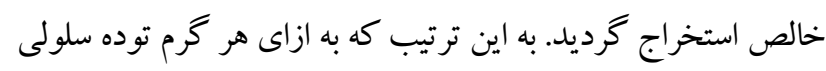

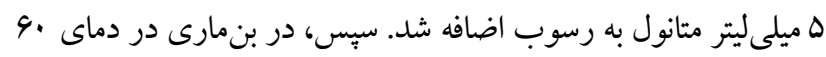

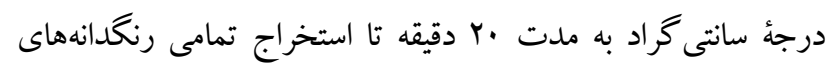

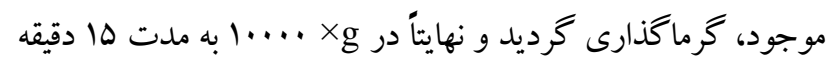

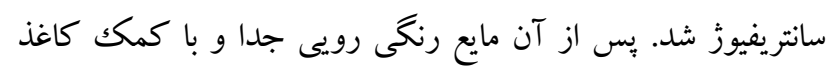

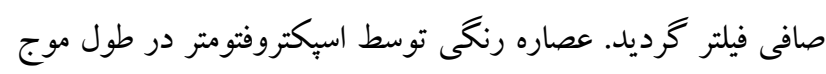

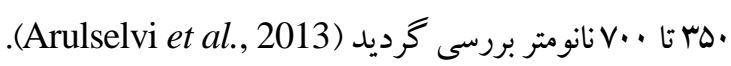

آناليز رنعدانه با HPLC

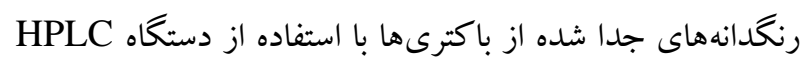

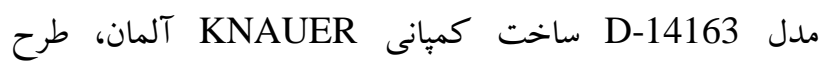
ايزو كراتيكك با ستون C18 به طول 90 سانتىمتر و قطر \&/4 ميلى متر

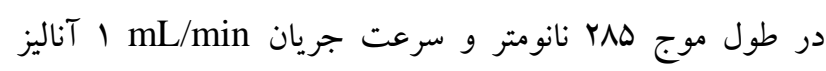

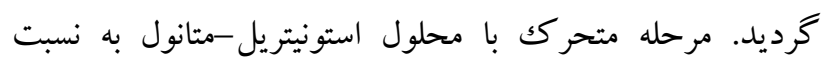

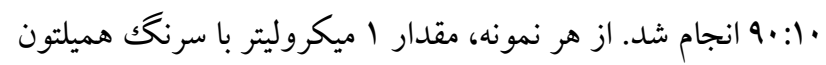

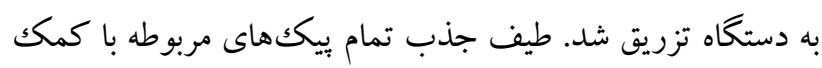
آشكارساز به صورت عكس ديجيتال ثبت گرديد.

\section{نثنايج \\ شناسايع جدايههاى باكتريايى}

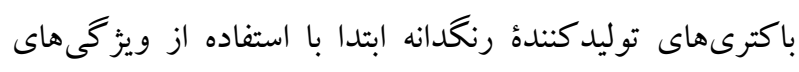

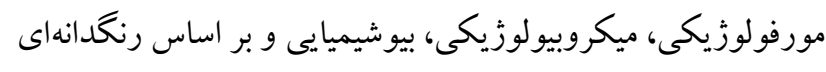

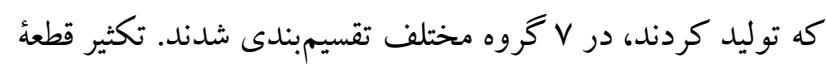

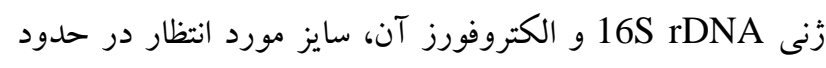
الم جفتباز را نشان داد. شناسايى مولكولى جدايهها با تععين

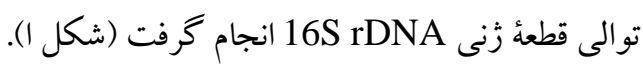

\section{آناليز استيكتروفتومترى}

Rhodococcus واكترىهاى Staphylococcus epidermidis رنگدانه نارنجى، Dietzia natronolimnaea g ruber Citricoccus alkalitolerans, Micrococcus aloeverae
باكترىهاى توليد كنندة رنگگانه ابتدا از نظر مورفولوزى و روش

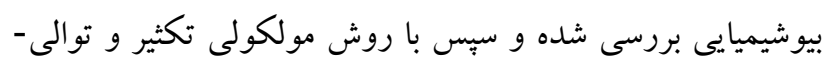

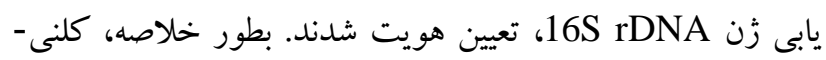
هاى رنكى ظاهر شده روى محيط BHI آكار جهت بر رسى بيشتر

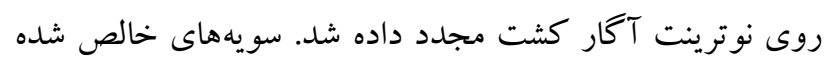

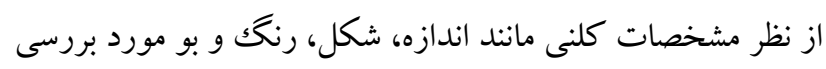

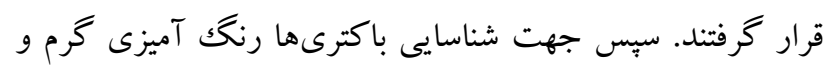
تستهاى بيوشيميايى از جمله تست اندول، حركت، متيل ردها و گس برسكائر، سيمون سيترات، تست اكسيداز، تست كاتالاز و وتئي

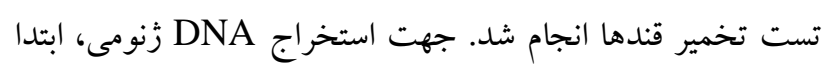

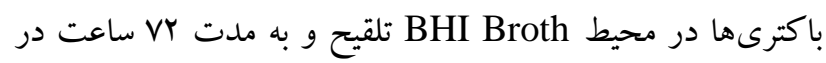
انكوباتور شيكردار قرار گرفت. DNA زٔنومى باكترى مها با استفاده

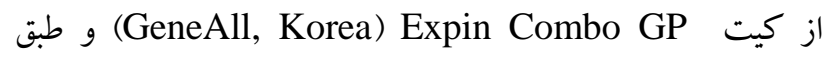
يروتكل شركت سازنده استخراج شد.

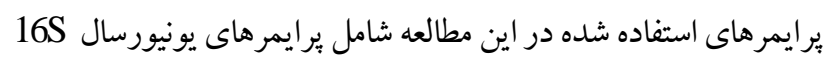

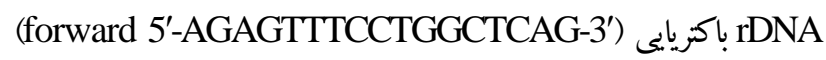
و (reverse 5'-ACGGCTACCTTGTTACGATT-3') ro (Lane, 1991)

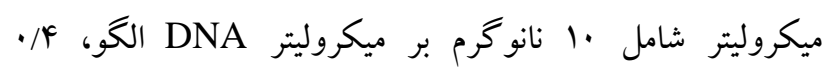

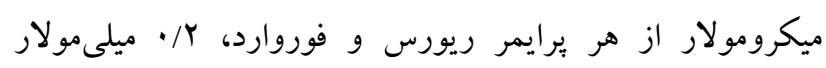

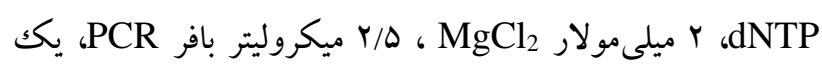

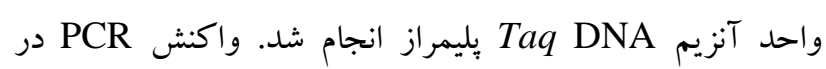

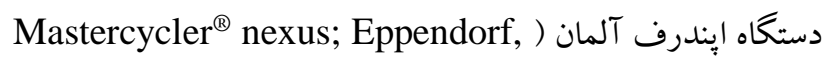

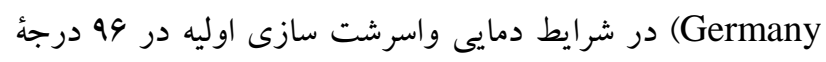

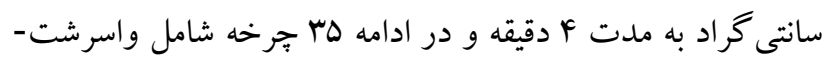

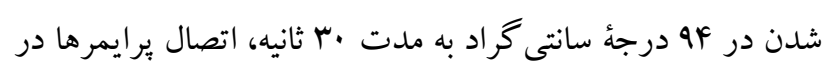

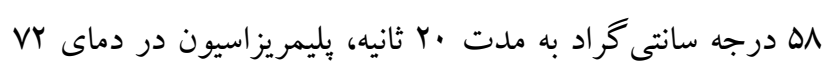

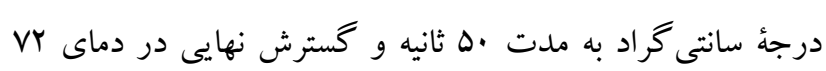

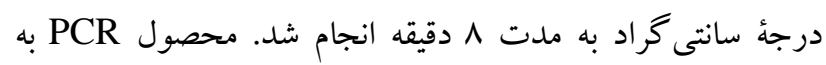

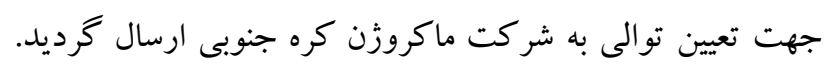

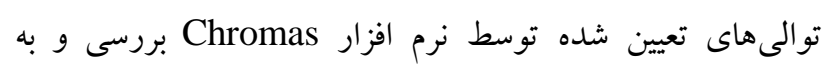

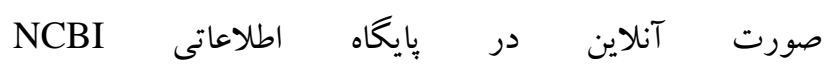
- (https://blast.ncbi.nlm.nih.gov/Blast.cgi)

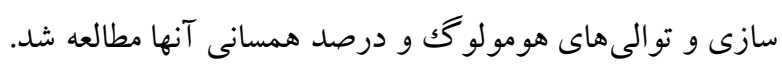
جداسازى رنعدانه 
آناليز رنخدانههاى جدايههاى باكتريايى با استفاده از روش HPLC

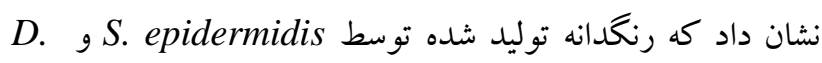
S. بتاكاروتن بود. در منحنى مربوط بـ natronolimnaea

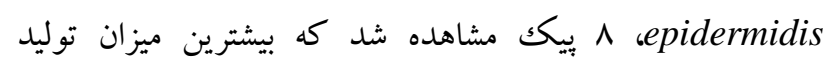
بتاكاروتن در زمان بازدارى (Ret time) منحنى D. natronolimnaea دو بيكك مشاهده گرديد كه در مار 9/MFr Ret time
R. zopfii رنخدانه قرمز و Arthrobacter agilis رردانه رنگدانه صورتى توليد كردند (شكل Y). آناليز جذب نورى بيخمان با دستخاه اسبكتروفتومتر UV-VIS نشان داد كه ميزان جذب نورى

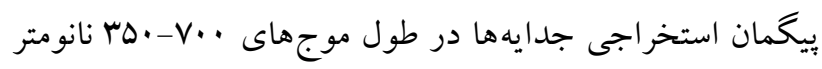
S. epidermidis بود كه بيشترين ميزان جذب در جدايههاى در طول موج بf

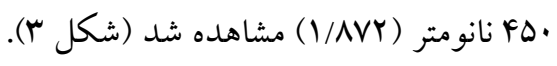

آناليز HPLC

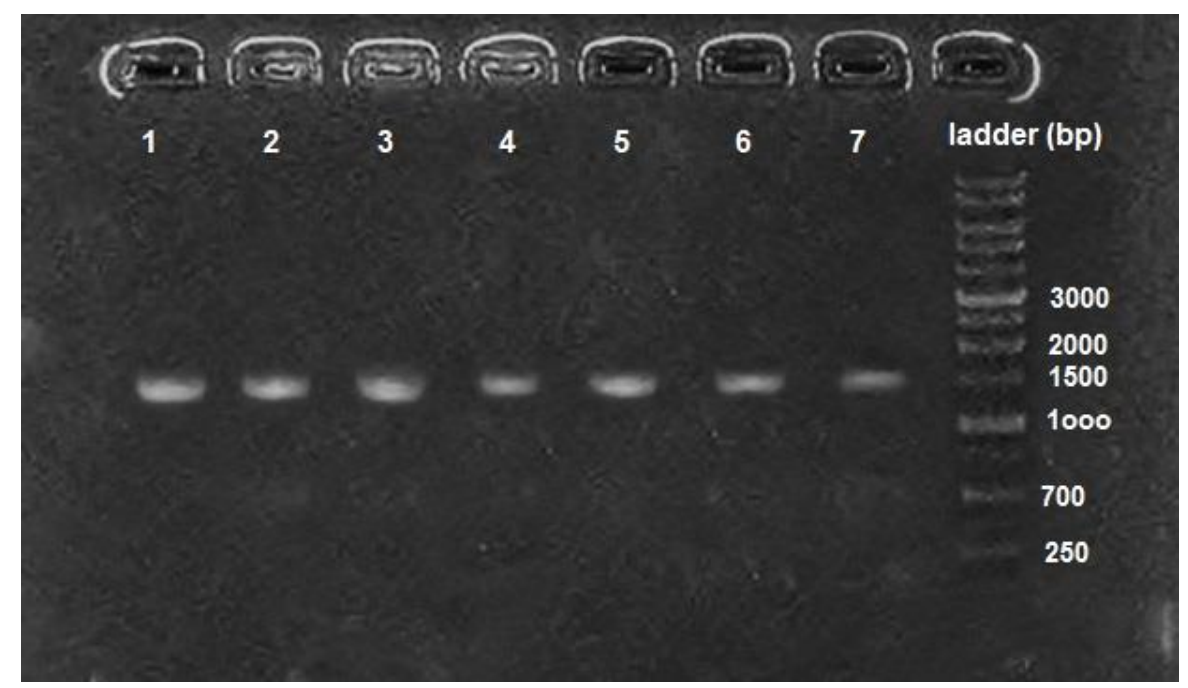

شكل 1- تكثير قطعه 16S rDNA جدايههاى باكتريايى. ا. استافيلو كو كوس إيدرمايديس. r. ميكروكو كوس آلوئورا. r. سيتريكو كوس آلكاليتولرانس. ع. رودو كو كوس زوفتى. 0.

Fig. 1. Amplification of $16 \mathrm{~S}$ rDNA fragment of bacterial isolates. 1. S. epidermidis. 2. M. aloeverae. 3. C. alkalitolerans. 4. R. zopfii. 5. A. agilis. 6. D. natronolimnaea. 7. R. ruber.

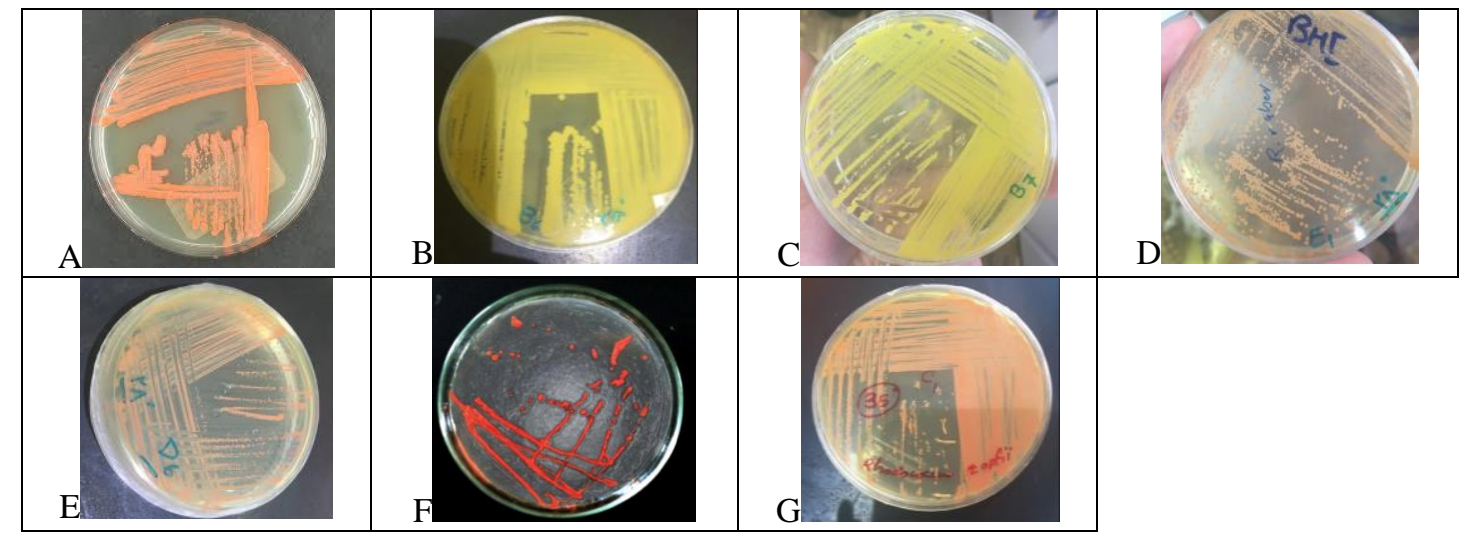

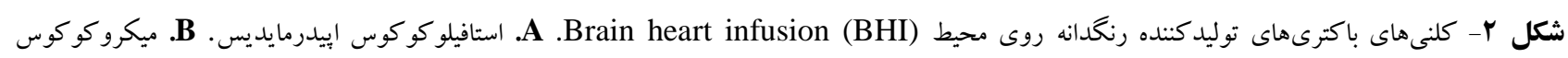

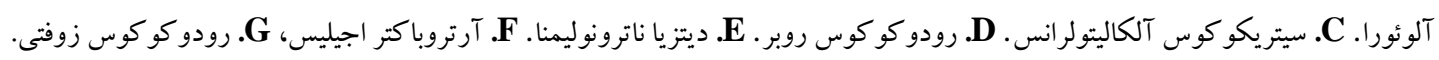

Fig. 2. The colonies of pigment-producing bacteria on BHI agar. A. S. epidermidis. B. M. aloeverae. C. C. alkalitolerans. D. R. ruber. E. D. natronolimnaea. F. A. agilis. G. R. zopfii. 

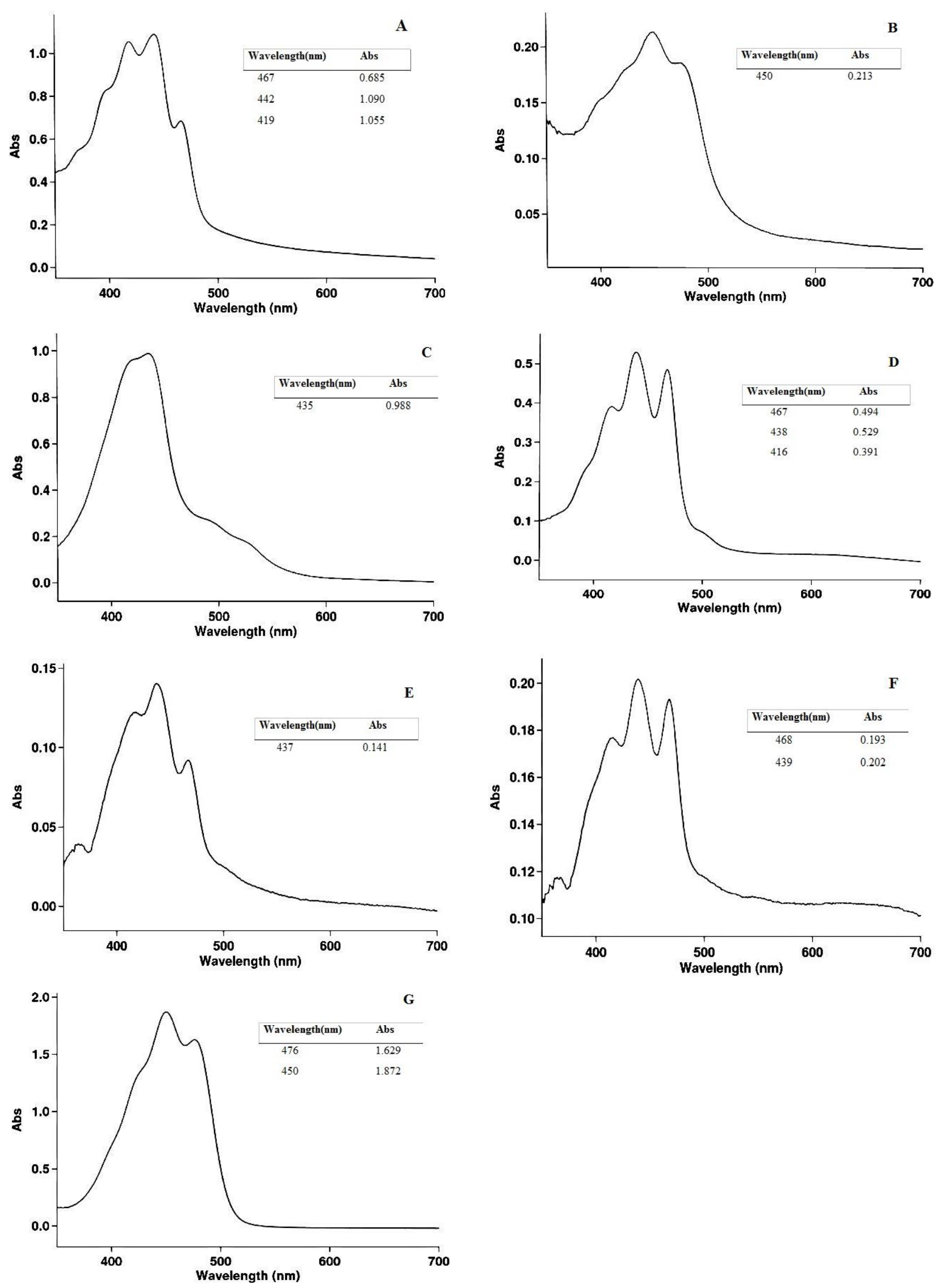

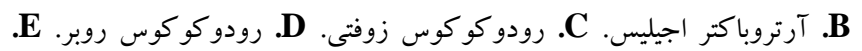

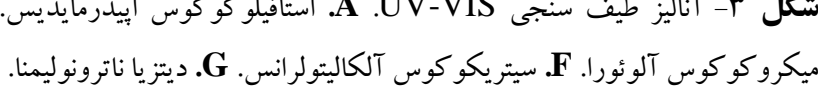

Fig. 3. UV-VIS spectroscopy analysis. A. S. epidermidis. B. A. agilis. C. R. zopfii. D. R. ruber. E. M. aloeverae. F. C. alkalitolerans. G. D. natronolimnaea. 

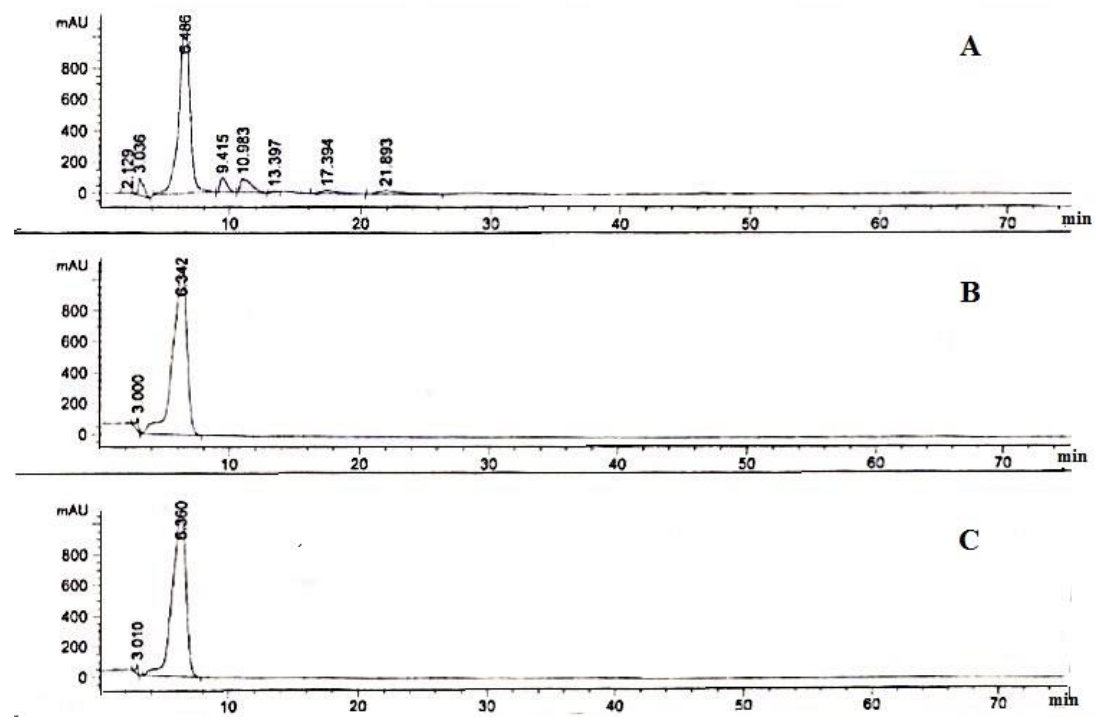

شكل ع- دياكرام آناليز ييخمان بتا كاروتن در دو باكترى Datronolimnaea S. epidermidis در مقايسه با بتاكاروتن استاندارد با HPLC. .standard beta-carotene .C .D. natronolimnaea .B.S. epidermidis.A

Fig.4. Beta-carotene pigment analysis in the two bacteria S. epidermidis and D. natronolimnaea compared with standard beta-carotene by HPLC method. A. S. epidermidis. B. D. natronolimnaea. C: standard beta-carotene.

جدول ا- نتايج آناليز ييخمان بتاكاروتن با روش HPLC در دو باكترى D. natronolimnaea S. epidermidis و مقايسه آن با نمونه استاندارد بتا كاروتن.

Table 1. The results of the analysis of beta-carotene pigment by HPLC method in two strains of Staphylococcus epidermidis and Dietzia natronolimnaea and comparison with the standard beta-carotene sample.

Signal 1: Staphylococcus evidermidis, Sig:485

\begin{tabular}{|c|c|c|c|c|c|c|}
\hline Peak \# & Ret Time $(\mathbf{m i n})$ & \multicolumn{1}{c}{ Type } & \multicolumn{1}{c|}{ Width $(\mathbf{m i n})$} & \multicolumn{1}{c|}{ Area $\left(\mathbf{m A U} \mathbf{S}^{\mathbf{S}}\right)$} & \multicolumn{1}{c|}{ Height $(\mathbf{m A U})$} & \multicolumn{1}{c|}{ Area \% } \\
\hline $\mathbf{1}$ & 2.129 & BB & 0.3004 & 38.90742 & 1.70379 & 0.0477 \\
\hline $\mathbf{2}$ & 3.036 & BB & 0.3582 & 3062.71753 & 110.91557 & 3.7514 \\
\hline $\mathbf{3}$ & 6.486 & BB & 0.9121 & $6.51254 \mathrm{e} 4$ & 1091.43066 & 79.7698 \\
\hline $\mathbf{4}$ & 9.415 & BB & 0.5694 & 3294.02783 & 92.06458 & 4.0347 \\
\hline $\mathbf{5}$ & 10.983 & BB & 0.8241 & 5251.63623 & 86.03801 & 6.4325 \\
\hline $\mathbf{6}$ & 13.397 & BB & 0.4627 & 246.31612 & 6.70303 & 0.3017 \\
\hline $\mathbf{7}$ & 17.394 & BB & 1.2017 & 1883.46155 & 19.69509 & 2.3070 \\
\hline $\mathbf{8}$ & 21.893 & BB & 1.3765 & 2739.23340 & 23.45526 & 3.3552 \\
\hline Total: & & & $8.16417 \mathrm{e} 4$ & 1432.00599 & \\
\hline
\end{tabular}

Signal 2: Dietzia natronolimnaea, Sig:485

\begin{tabular}{|c|c|c|c|c|c|c|}
\hline Peak \# & Ret Time (min) & Type & \multicolumn{1}{c|}{ Width $(\mathbf{m i n})$} & \multicolumn{1}{c|}{ Area (mAU*S) } & \multicolumn{1}{c|}{ Height (mAU) } & Area \% \\
\hline $\mathbf{1}$ & 3.000 & BB & 0.1868 & 198.56511 & 14.59161 & 1.3368 \\
\hline $\mathbf{2}$ & 6.342 & BB & 1.0815 & $1.46556 \mathrm{e} 4$ & 195.28575 & 98.6633 \\
\hline Total:
\end{tabular}

Signal 3:|standard sample(betacarotene), Sig:485

\begin{tabular}{|c|c|c|c|c|c|c|}
\hline Peak \# & Ret Time $(\mathbf{m i n})$ & \multicolumn{1}{c|}{ Type } & \multicolumn{1}{c|}{ Width $(\mathbf{m i n})$} & \multicolumn{1}{c|}{ Area $\left(\mathbf{m A U} \mathbf{A U}^{*} \mathbf{S}\right)$} & \multicolumn{1}{c|}{ Height $(\mathbf{m A U})$} & Area \% \\
\hline $\mathbf{1}$ & 3.010 & BB & 0.1628 & 81.39305 & 7.15234 & 0.8653 \\
\hline $\mathbf{2}$ & 6.360 & BB & 1.0553 & 9324.85156 & 128.09224 & 99.1347 \\
\hline Total: & & & 9406.24461 & 135.24458 &
\end{tabular}


از روش TLC ، HPLC و طيف سنجى UV استفاده شد. نتايج آناليز طيف سنجى، بيشترين ميزان جذب در • • ب نانومتر را نشان

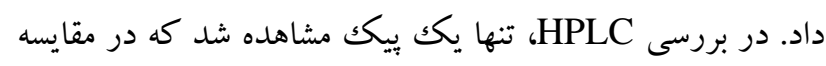

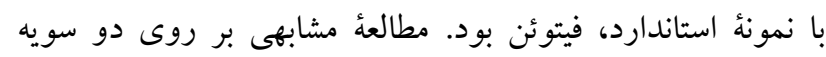

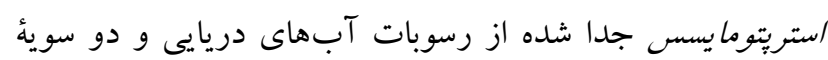

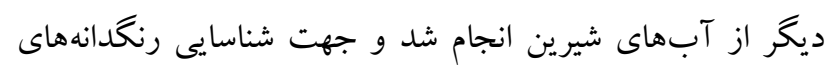

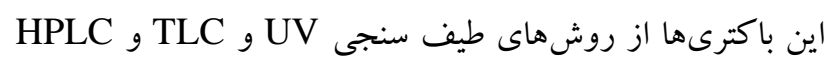

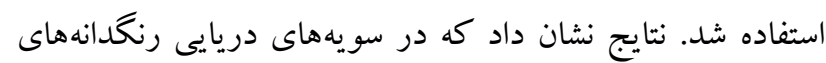

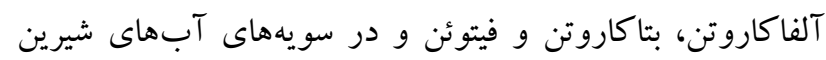

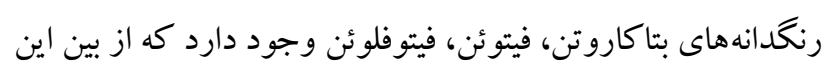

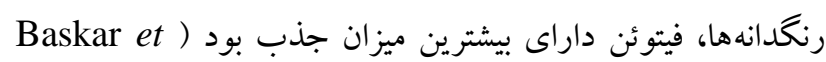

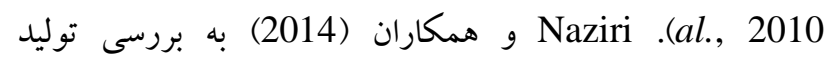
كاروتنوئيدها توسط ايزولههاى باكتريايى جدا شده از درياجه

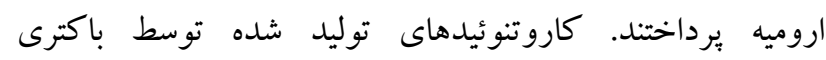
Halorubrim chaviater

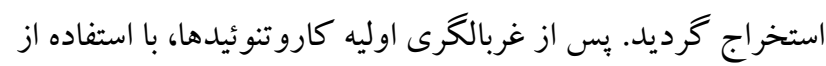
روشهاى طيف سنجى UV-VIS و LC-MS و TLC مورد

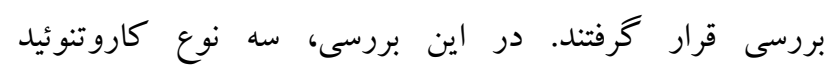

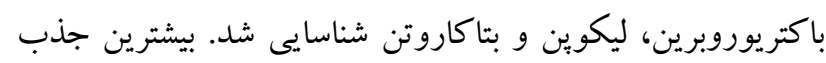

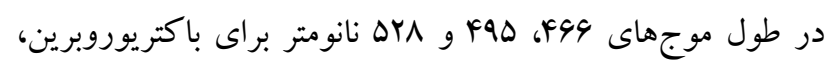
F

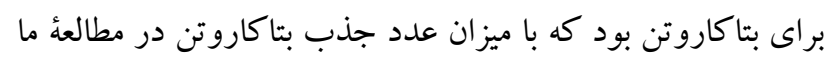

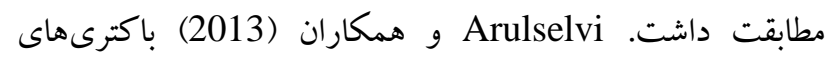
توليدكننده بيخمان نارنجى را از خاكك جداسازى نمودند. آناليز اين واين

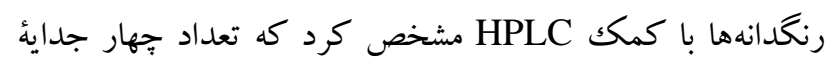

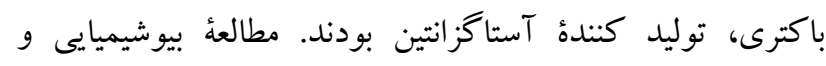
بر 16S rDNA اين جهار جدائُ باكترى نشان داد كه دو جدائ Exiguobacterium aurantiacum و و دو جرى جدائ Exiguobacterium profundum Arulselvi

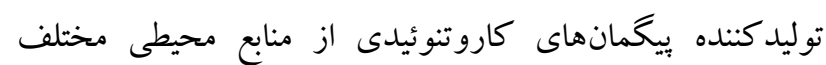

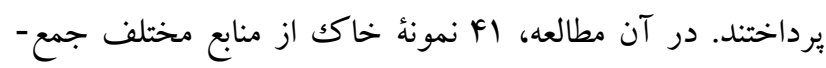

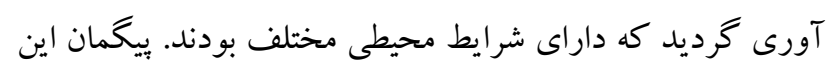

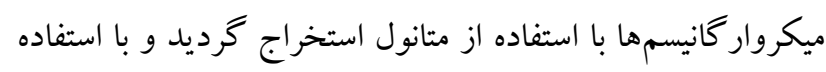

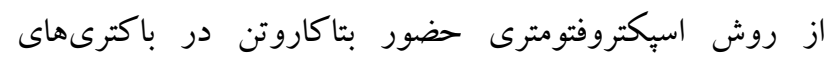

بتاكاروتن استاندارد ( Ret time

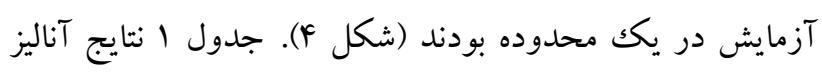
S. epidermidis در دو سيخمان بتاكاروتن با روش

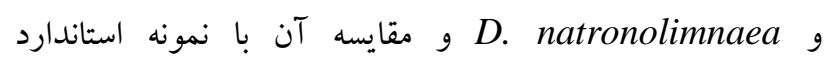
بتاكاروتن به عنوان شاخص كاروتنوئيدى را نشان مىدهد.

بحتماً أهميت و فراوانى كاروتنوئيدها در طبيعت به علت مسير نسبتاً ساده بيوسنتز آنها است كه اين امر در گياهان عالى و جلى جلبككها ثابت شده است و در باكترىها و مخمرها هم ديده مىشوداد

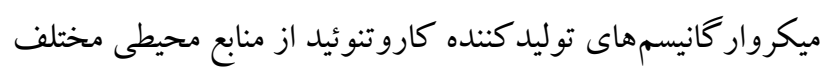

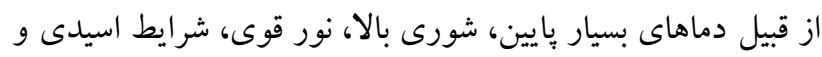

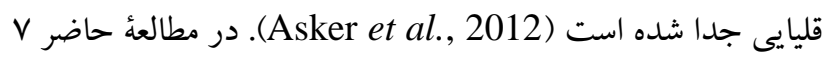
كونهُ مختلف باكترىهاى توليدكننده كاروتنوئيد ازخاكى

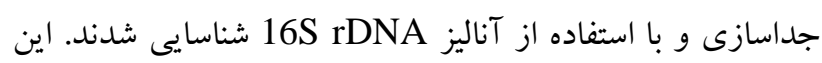

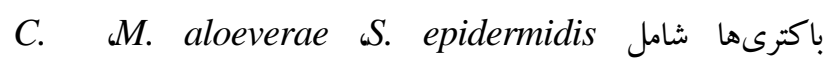
$D$. natronolimnaea , $R$. ruber $R$. zopfii ،alkalitolerans بودند كه رنخدانه شاخص با استفاده از روش طيفسنجى و و

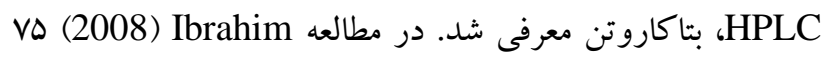
سويه باكتريايى از نمونههاى رسوب دريا جداسازى شد كه از بين

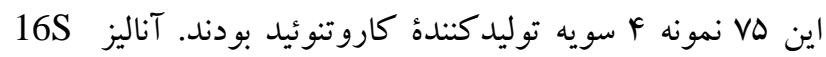
Bacillus Halomonas نشان داد كه اين سويهها rDNA Micrococcus luteus و Micrococcus sp. ،aquimaris هستند. كاروتنوئيدهاى اصلى در .Micrococcus sp شناسايى و به . وسيله LC/MS و طيف سنجى UV بررسى گرديد. آناليز اين

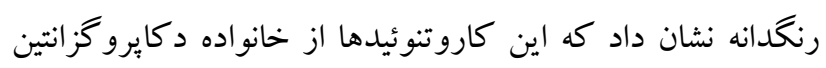

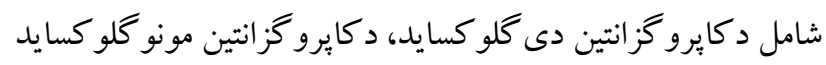

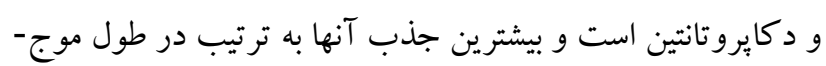

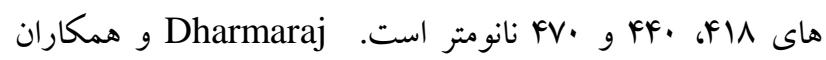
(2009) اكتينوميستهاى دريايى به نام استريتومايسس توليدكننده

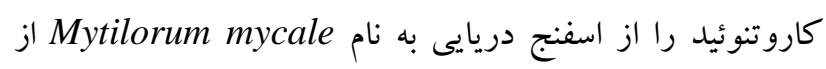
سواحل جنوب غرب هند و با كمك محيط كليسرول آسيارزين آكار (ISP-5) جداسازى نمودند. سويههاى /ستريتومايس غنس

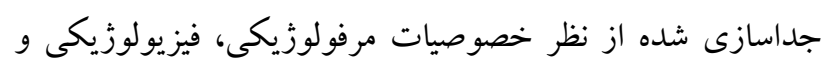

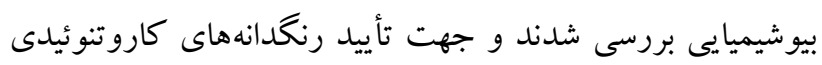




\section{REFERENCES}

Ahmad, W.A., Ahmad, W.Y.W., Zakaria, Z.A. and Yusof, N.Z. 2012. Isolation of pigment-producing bacteria and characterization of the extracted pigments. In: Application of bacterial pigments as colorant. Springer, Berlin, Heidelberg 25-44.

Arulselvi, I., Sasidharan, P., Raja, R., Karthik, C. and Gurumayum, R.S. 2013. Isolation and characterization of yellow pigment producing Exiguobacterium sp. - J. Biochem. Technol. 4: 632-635.

Arulselvi, I.P., Umamaheswari, S., Sharma, R.G., Karthik, C. and Jayakrishna, C. 2014. Screening of yellow pigment producing bacterial isolates from various ecoclimatic areas and analysis of the carotenoid produced by the isolate. - J. Food Process Technol. 5: 292.

Asker, D., Awad, T.S., Beppu, T. and Ueda, K. 2012. Isolation, characterization, and diversity of novel radiotolerant carotenoid-producing bacteria. In: J.-L. Barredo (ed). Microbial carotenoids from bacteria and microalgae: methods and protocols. -Humana Press, New York. pp: 21-60.

Asker, D., Beppu, T. and Ueda, K. 2007. Unique diversity of carotenoid-producing bacteria isolated from Misasa, a radioactive site in Japan. - Appl. Microbiol. Biotechnol. 77: 383-392.

Astuti, W., Radjasa, O. K., Karwur, F.F. and Rondonuwu, F.S. 2016. Identification of Carotenoids in Halimeda macroloba Reef Associated Bacteria. - Indonesian J. Marine. Sci. Ilmu Kelautan 21: 151-160.

Balraj, J., Pannerselvam, K. and Jayaraman, A. 2014. Isolation of pigmented marine bacteria Exiguobacterium sp. from peninsular region of India and a study on biological activity of purified pigment. - Int. J. Sci. Technol. Res. 3: 375-384.

Baskar, V., Madhanraj, P., Kanimozhi, K. and Panneerselvam, A. 2010. Characterization of carotenoids from Streptomyces sp. of marine and fresh water environment.- Arch. Appl. Sci. Res. 2: 380-388.

Dharmaraj, S., Ashokkumar, B. and Dhevendaran, K. 2009. Fermentative production of carotenoids from marine actinomycetes. - Iranian J. Microbiol. 1: 36-41.

Goswami, B. and Bhowal, J. 2014. Identification and characterization of extracellular red pigment producing bacteria isolated from soil. - Int. J. Curr. Microbiol. App. Sci. 3: 169-176.

Ibrahim, A.S.S. 2008. Production of carotenoids by a newly isolated marine Micrococcus sp. - Biotechnol. 7: 469-474.

Lane, D.J. 1991. 16S/23S rRNA Sequencing. In: Stackebrandt, E. and Goodfellow, M. Eds. Nucleic Acid Techniques in Bacterial Systematics, John Wiley \& Sons Ltd., West Sussex, 115-147.

Naziri, D., Hamidi, M., Hassanzadeh, S., Tarhriz, V., Zanjani, B.M., Nazemyieh, H., Hejazi, M.A. and Hejazi, M.S. 2014. Analysis of carotenoid production by Halorubrum sp. TBZ126; an extremely halophilic archeon from Urmia Lake. - Adv. Pharm. Bull. 4: 6167

Paniagua-Michel, J., Olmos-Soto, J. and Ruiz, M.A. 2012. Pathways of carotenoid biosynthesis in bacteria and microalgae. - Methods Mol. Biol. 892: 1-12.
توليد كنندة كاروتنوئيد بررسى گرديد و مشخص شد كه رنگُانههاى مورد بررسى داراى بيشترين جذب در طول موج ·لها نانومتر بودند. Goswami و Bhowal (2014) باكترىهاى توليد كنندة بيخمان قرمز را از خاكى جداسازى كردند. طبق بررسىهاى انجام شده با كمك روشهاى مرفولوزيكى، فيزيولوزيكى و پيارامترهاى بيوشيميايى مشخص شد كه اغلب اين جدايهها متعلق به جنس باسيلوس بودند. رنكَ قرمز اين باكترىها با كمكك اتانول اسيدى

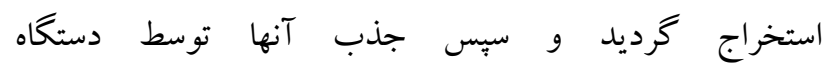
اسبكتروفتومترى UV-VIS مورد بررسى قرار كرفت كه بيشترين ميزان جذب آنها بطور متوسط در . VFF نانومتر بود. امروزه، توليد رنخدانهُ كاروتنوئيد از منابع ميكروبى داراى مزاياى فراوانى است. سهولت شرايط تكثير ميكروار گانيسمها و توليد انبوه اين فر آورده با استفاده از دستكارىهاى زيستى و زنتيكى ميسر است. با بومى كزينى سويه هاى باكتريايى توليد كنتده كاروتنوئيد و بهينهازي

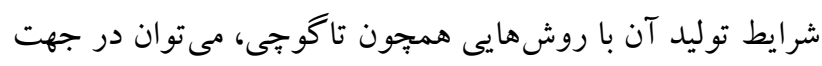
صنعتى سازى اين محصول بارزش كام برداشت.

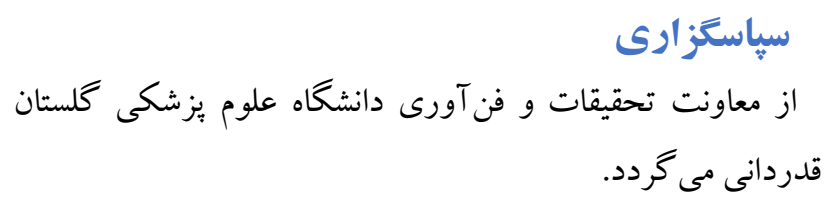


Parmar, M. and Phutela, U.G. 2015. Biocolors: the new generation additives. - Int. J. Curr. Microbiol. App. Sci. 4: 688-694.

Rymbai, H., Sharma, R. and Srivastav, M. 2011. Biocolorants and its implications in Health and Food Industry-A Review. - Int. J. Pharm. Tech. Res. 3: 2228-2244.

Samyuktha, S. and Mahajan, S.N. 2016. Isolation and identification of pigment producing bacteria and characterization of extracted pigments. - Int. J. App. Res. 2: 657-664.
Seifzadeh, M., Khanipour, A. and Morady, Y. 2016. The evaluation of the quality of beta-carotene derived from Azolla Filiculoides in the Anzali Wetland using the alkaline hydrolysis method in summer. - Iran. Sci. Fisheries J. 25: 75-86.

Sinha, S., Choubey, S., Ajay Kumar, A. and Bhosale, P. 2017. Identification, characterization of pigment producing bacteria from soil and water and testing of antimicrobial activity of bacterial pigments. - Int. J. Pharm. Sci. Rev. Res. 42: 119-124.

How to cite this article:

Solouki Nezhad, R.S., Asaadi, H., Eshaghi Milasi, Y. and Yazdansetad, S. 2019. Isolation and molecular identification of carotenoid-producing bacteria. - Nova Biol. Reperta 6: 61-69.

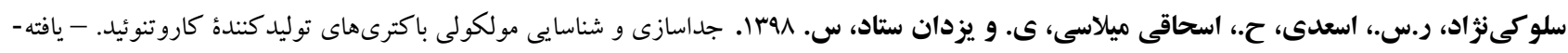
هاى نوين در علوم زيستى 9: 99-91. 